\title{
Managing University Social Responsibility
}

\author{
Loreta Tauginiené $^{1}$, Saule Mačiukaitè-Žviniené ${ }^{2}$ \\ ${ }^{1}$ Institute of Management, Mykolas Romeris University, Lithuania \\ ${ }^{2}$ Institute of Political Sciences, Mykolas Romeris University, Lithuania
}

\begin{abstract}
The university mission is considered as its social function, and the university is a pivot of strategic social transformation. The culture of changes mostly tends to increase the organisational flexibility and orientation towards the market needs. In embracing changes, individual researchers, units and organisations should build a more competitive and entrepreneurial approach and be more accountable for the performance. The integration of declared principles, values and commitments into the overall organisational activities, managerial processes and practices creates added value for the institutionalisation of university social responsibility. In this respect, the aim of this paper is to examine empirically how vice-rectors for research and deans of faculties comprehend and manage social responsibility in research performance. Fifteen informants were interviewed: vice-rectors for research and deans of faculties, representing at least six Lithuanian state universities. Using the method of semi-structured interview the collected data were then analysed in the context of the grounded theory. The research findings demonstrate that the vice-rectors for research and deans of faculties formally understand the responsibility; while it indicates the narrow attitude to both mission and responsibility of the university. Such perception of responsibility hampers the development of university social responsibility with corresponding societal expectations, and its systematic implementation in internal processes.

Keywords: Commitment, Research performance, Social responsibility, Stakeholders, University.
\end{abstract}

\section{INTRODUCTION}

A university's mission frequently refers to the satisfaction of individual and societal needs from the educational perspective, creating a competitive advantage on the basis of the development of personal knowledge. This university mission is considered as its social function [1], and the university is a pivot of strategic social transformation $[2 ; 3$, p. 86; 4]. Consequently, the traditional values of university, its organisational culture should find their place in the shifting environment, contribute to societal progress and be able to adapt, anticipating changes without prejudice to the interests of other stakeholders. Staškevičiūtè, Neverauskas [5] refer to the visionary university, Tierny (op. cit., 1998), Leja [6] and Gaete Quezada [7] characterise it as socially responsible.

The values are the significant part of the development of the organisational culture, which influences organisational behaviour and its efficiency. Nevertheless, this culture is also the means for reciprocity and the coordination of organisational and individual interests, which turns up motivating the staff and towards the innovation-driven outcomes $[8$, p. 101; 9, p. 92]. Increasingly, the important elements of higher education's potential become the intangible factors. For instance, the image of the university (not only state allocations) has a decisive impact on the success of its performance or even its survival [10]. In this case, it is essential to learn not only what to change, but also how to do it.

The flow of research on social responsibility has started after A. B. Carroll's works, where he analyses the development of corporate social responsibility $[11 ; 12 ; 13]$. In his view, the conceptualisation of corporate social responsibility included the idea that it has not only economic and legal obligations, but also ethical and philanthropic responsibilities. It is upon the ethical perspective that our paper is based. The ethical aspect of social responsibility in the performance of university shows how actors, being involved in ethics institutionalization, understand their responsibility in the context of research performance, what their scope of responsibility is and how they contribute to the implementation of social responsibility from the perspective of ethics. Ethical aspect is important for the understanding of responsibility and its benefit which helps to carry out changes in organizational culture and create ethically friendly research environment. Recently, the statements about the deviations of ethical behaviour of politicians and researchers have appeared in media; therefore, this paper seeks to go deep into the awareness of the ethical dimension of university social responsibility. The unbridled deviations of behaviour hamper even universities, mirrors of the knowledge society and economy. Respectively, managerial solutions serve to restrain unethical behaviour.

The contributions of this paper are three-fold. First, we explain the significance of social responsibility for university. Secondly, we relate the university social responsibility to the management of research 
performance. And, thirdly, after the developed interrelations in the previous sections, the methodology and findings guide us to the research results.

\section{UNIVERSITY SOCIAL RESPONSIBILITY}

The necessary factors for the well-being of a university are defined as: organisational values, quality culture, investments, intellectual capital, sustainable development and socially responsible performance managerial systems, image, motivated staff, change management and so on [14]. Therefore, the impact of the implementation of university's social responsibility policy can be considered from the perspective of the following dimensions $[15$, p. 144; 16, p. 9]:

Organisational impact (commitments): a university should respect its personnel and students and, respectively, its behaviour in the external environment should be compliant with its mission and values.

Educational impact (self-diagnosis): this relates to quantitative and qualitative surveys of university staff and students in university management, educational services, knowledge transfer and research performance, and social inclusion.

Cognitive impact (accountability): a university is interested in what knowledge should be created and what is its social importance for learners.

- $\quad$ Social impact (agreement): the solutions of issues, creation of social capital or access of knowledge by everybody encourage societal development on the strength of the university mission and values, and its demonstrated actions.

Mostly, the culture of change tends to increase organisational flexibility and the orientation towards market needs. In embracing change, individual researchers, units and organisations should construct a more competitive and entrepreneurial approach and be more accountable for their activity [17, p. 7]. The integration of the declared principles, values and commitments in the overall organisational activities, managerial processes and practices, for instance, into personnel management, risk management, and quality management [18, p. 15] creates added value for the institutionalisation of university social responsibility. This means that the integration of the declared principles, values and commitments builds the university social responsibility, meeting societal expectations; and the university social responsibility indicates the potency of moral values. This potency may be the imperative where the inefficient legal rules occur and in the case of increasing the confidence between the university and the society, herewith raising the university reputation $[19, \mathrm{p} .1070]$.

\section{SOCIAL RESPONSIBILITY IN RESEARCH PERFORMANCE}

In line with global processes and worldwide changes, it is crucial for the university to embed its positions in research and creation of applicable and inapplicable knowledge. The institutional position focuses on the ratio of researchers and students, quality of published works, outcome of the research performance (for instance, the application of index according to the type of research work), and number of implemented or to-beimplemented research projects and so on. The study process and research performance in the university are inherent, and the distinct attribute of the university is namely the fact that the university carries out research, creating the scientific knowledge [20, p. 62-64; 21, p. 278], and this refers to "research university".

The research gets closer to society when society becomes part of the research. The global processes affect the modification of university, especially its research performance: open access research databases, peerreviewed open access online journals, massive open online courses, digital libraries and other processes may give the impression that the university will speedily become a virtual entity in its overall activities. The likely consequences of these processes lead to a threat to traditional values. In the $21^{\text {st }}$ century, pragmatic challenges are inevitable, and to perform research on the ideological basis is detrimental; however, it is crucial to pay attention to how university values could transform, and whether the university would be able to remain loyal to its values. In this respect, the separation of moral and economic values is significant in research performance [22, p. 598-599]. The economic value comes out when, for instance, the customer for the commissioned research buys the completed research on teaching social responsibility in the university, but the moral value of this research lies in that how these subjects are taught and what is their added value. Education as a good has a moral value (the responsibility of a university academic consists of how his/her professionalism manifests and how the academic communicates publicly), therefore the research itself is a moral value, free-standing of economic value, as the research findings contribute to the well-being of the society [22]. This dilemma stimulates vivid discussions.

\section{METHODOLOGY}

Research sampling. The sample was selected through the targeted selection of purposive sampling. The main criterion of the selection of informants was the participation in design of institutional research policy and its implementation. According to this criterion, the main actors in research policy were interviewed - vicerectors for research and deans of faculties, representing all fields of science and arts. Moreover, informants have 
the academic experience in the management of doctoral studies from the perspective of different roles. For instance, as scientific supervisor (consultant), member of the doctoral committee, lecturer, examiner, member of the defence board. Also, they have some experience in scientific publishing as publisher, reviewer, and author. Taking into consideration all these experiences, informants shared them by their statements. The professional experience at higher education institution varies from 7,1 to 21,8 years, therefore, we assume that the experience of informants and their competences at the university are sufficient.

This research is a small-scale research, and it does not show the patterns, but it guides to the wide spectrum of answers.

Data collection. There is an incoherent body of research on university social responsibility, examining values of university and their impact on research performance. Mostly, studies focus on the transformation of students' personal values as the outcome of the quality of higher education (what and how does the university teach?). To our knowledge, there has been some empirical research that has investigated the issue of the quality assurance of university research performance as well as the effectiveness and efficiency of research performance. In this respect, in line with ethical issues of research performance, the data was collected using semi-structured interviews. Fifteen informants were interviewed: vice-rectors for research (6) and deans of faculties (9), representing at least six Lithuanian state universities (see Table 1).

\begin{tabular}{|l|l|l|l|l|}
\hline Informants & $\begin{array}{l}\text { Number } \\
\text { universities }\end{array}$ & $\begin{array}{l}\text { Number } \\
\text { informants }\end{array}$ & $\begin{array}{l}\text { Average of } \\
\text { professional } \\
\text { experience* } \\
\text { (year) }\end{array}$ & $\begin{array}{l}\text { Average of } \\
\text { academic experience } \\
\text { (year) }\end{array}$ \\
\hline Vice-rectors for research & 6 & 6 & 7.3 & 19.8 \\
\hline Deans of faculties & 5 & 9 & 6.9 & 23.7 \\
\hline
\end{tabular}

*The average is calculated according to the duration of the current position of informant.

\section{Table 1. Characteristic of informants}

The collected data were then analysed in qualitative perspective, in terms of the grounded theory.

During the semi-structured interviews, more comprehensive data were collected. Informants provided answers to the open questions. The questions were formulated according to the contextual situations in the literature, which determined the origins of unethical behaviour or some managerial mistakes for ethical research performance. Seeking to delve deeply into the research question "How is the university social responsibility understood?" informants answered to the following questions - What activities and actions show the responsibility at the university? What does responsibility focus on? How are the mentioned activities related to the research performance? How is ethics reflected contextually?

Data analysis. Vice-rectors for research and deans of faculties are involved at the same stage of university management: planning, implementation, monitoring and evaluation. Their performance and activities are different in the scope of engagement at certain managerial levels. The formation of university strategic performance by strategic decision making shows the input of the responsibility of vice-rectors for research and deans of faculties, while the implementation of university strategic performance in studies and research refers to the process. Then, the output of performance and activities demonstrates the interrelation, benefit and consequences of behaviour, typical to performance. In this case, the interrelation of process operations helps finding the answer, whether the performance and activities are aligned and complement each other, even where they are carried out independently of each other (see Fig. 1).

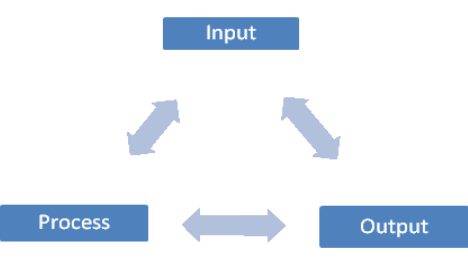

Fig. 1 Logic of research data analysis

The benefit of performance and activities indicates the added value and impact of responsibility. Along with the same line of reasoning, the data collection was continued until the saturation has been achieved.

V.

RESEARCH FINDINGS

Following the logic, described in the section on methodology (input - process - output; Fig. 1), the performance and activities of vice-rectors for research and deans of faculties were mapped (Tables 2-5) 
according to the stages of management. Each quadrant of the map indicates the spectrum of performance and activities which are not put in to hierarchical order. The quotations of the interview are presented in the in vivo approach.

\begin{tabular}{|c|c|c|c|}
\hline & $\begin{array}{l}\text { VICE-RECTORS } \\
\text { RESEARCH }\end{array}$ & DEANS OF FACULTIES \\
\hline 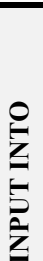 & 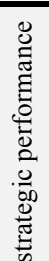 & $\begin{array}{l}\text { Formation of university image; } \\
\text { Planning of university quality in } \\
\text { performance; } \\
\text { Planning of accountability; } \\
\text { Planning of transfer of university } \\
\text { values; } \\
\text { Formation of informal communication } \\
\text { with community. }\end{array}$ & $\begin{array}{l}\text { Planning of strategic performance; } \\
\text { Planning of efficient performance; } \\
\text { Planning of creative performance. }\end{array}$ \\
\hline \multirow[b]{2}{*}{ 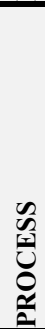 } & 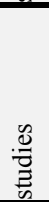 & $\begin{array}{l}\text { Formation of university traditions for } \\
\text { students; } \\
\text { Formation of university values for } \\
\text { students; } \\
\text { Planning of attraction of prospective } \\
\text { students. }\end{array}$ & $\begin{array}{l}\text { Planning of study process; } \\
\text { Forethought of efficient workload; } \\
\text { Planning of outcomes assessment. }\end{array}$ \\
\hline & 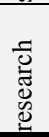 & $\begin{array}{l}\text { Planning of research impact on } \\
\text { society. }\end{array}$ & Forethought of research performance. \\
\hline 5 & $\begin{array}{l}\frac{0}{\pi} \\
\frac{\pi}{0} \\
\frac{0}{0} \\
\frac{\pi}{\pi}\end{array}$ & $\begin{array}{l}\text { Formation of influence on the external } \\
\text { environment. }\end{array}$ & $\begin{array}{l}\text { Formation of added value; } \\
\text { Forethought of the research and studies } \\
\text { impact. }\end{array}$ \\
\hline
\end{tabular}

\section{Table 2. Planning}

At the stage of planning, vice-rectors for research and deans of faculties point out the importance of performance quality in the strategic university performance. Deans of faculties explain the performance quality by efficiency and creative expression of performance. Vice-rectors for research relate the performance quality to the accountability and, also as deans of faculties, envisage the impact on the external environment - society, region, international area:

Planning of university quality in performance. The university implements its commitments through the study process - "environment is rather oriented towards the task and result. It's important that $<\ldots>$ [students] would be well trained, after then nobody would say that you do something wrong [at the university]" [P6].

Planning of efficient performance. The responsibility is implemented through the training of professionals; efficiency and outcomes of performance coincides with the market needs - "If everyone has fulfilled its duties likely better, the final result would be better" [D3], "we are responsible for that the study programmes would be of quality, $<\ldots>$ that [students], admitted to the university, would receive that what they expect and become good professionals in their field" [D4], "First of all, through the quality, and, second, through the results. The expression of our responsibility is mostly that one $\langle\ldots\rangle$, when we deliver the necessary people for the market and they correspond to the market needs" [D8].

Planning of creative performance. The responsibility is carried out through the planning and control - "[they] cannot plan their creative process, $<\ldots>$ thus, they cannot be responsible for that or they cannot be completely responsible for concrete results" [D5].

Forethought of efficient workload. The performance results of academics are identified with the funding assigned to the university - "the workload of the teaching staff consists of $\langle\ldots .>-$ study process, methodological performance and research performance $<\ldots>$ these results $<\ldots>$ bring the funding from Research Council of Lithuania" [D6].

Planning of research impact on society. The university mission to perform research is implemented through massification and the special target groups - "The performance on research dissemination includes wider layers of society $<\ldots>$ research production, oriented towards specialists, includes more narrow societal layers" [P1]. 
Formation of influence on the external environment. The expert works of staff influence the external environment - "We feel the responsibility for our local community and the impact on the region and at certain international context" [P2].

Forethought of the research and studies impact. The responsibility is oriented towards its potential impact "If there is a research performance, then towards the efficiency of research, its dissemination. If there are studies, towards the quality of studies" [D3].

Formation of added value. The accomplished commitments become the instrument of marketing - "[students] serve us as an advertisement" [D8].

The integral performance and forethought of its impact allow creating the added value of responsibility.

\begin{tabular}{|c|c|c|c|}
\hline \multirow[b]{2}{*}{ 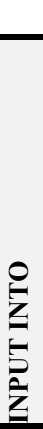 } & \multirow[b]{2}{*}{ 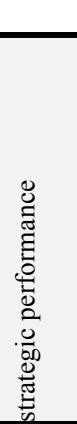 } & & DEANS OF FACULTIES \\
\hline & & 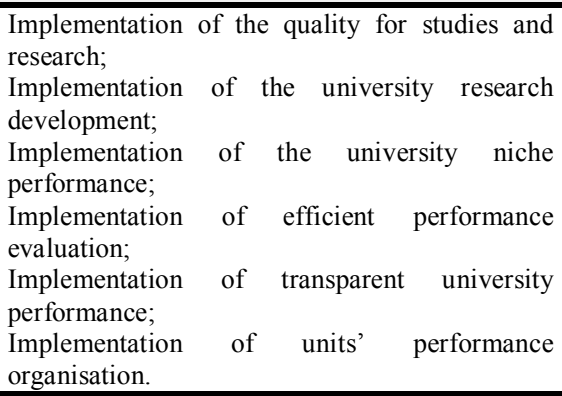 & $\begin{array}{l}\text { Coordination of creative performance; } \\
\text { Fulfilment of institutional policy; } \\
\text { Fulfilment of institutional commitments; } \\
\text { Fulfilment of responsibility for the implementation } \\
\text { of strategic performance; } \\
\text { Fulfilment of employee responsibility; } \\
\text { Fulfilment of unified document preparation; } \\
\text { Fulfilment of personnel governance; } \\
\text { Hierarchical fulfilment of strategic performance; } \\
\text { Fulfilment of institutional responsibility; } \\
\text { Fulfilment of information for employees. }\end{array}$ \\
\hline & $\stackrel{\mathscr{n}}{\stackrel{0}{\tilde{Z}}}$ & Implementation of the quality for studies. & $\begin{array}{l}\text { Coordination of study process; } \\
\text { Fulfilment of responsibility for students; } \\
\text { Coordination of pedagogical performance; } \\
\text { Fulfilment of pedagogical workload; } \\
\text { Coordination of personnel selection. }\end{array}$ \\
\hline 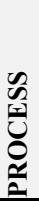 & 过 & 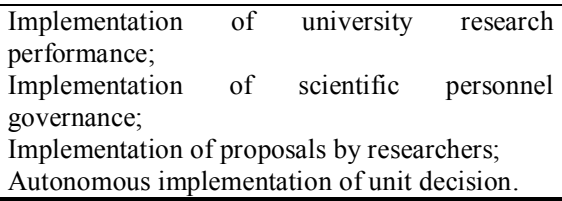 & $\begin{array}{l}\text { Fulfilment of university autonomous research } \\
\text { performance; } \\
\text { Fulfilment of responsibility for researchers. }\end{array}$ \\
\hline 它 & 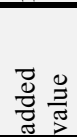 & $\begin{array}{l}\text { Implementation of the integration of studies and } \\
\text { research quality; } \\
\text { Implementation of societal needs. }\end{array}$ & $\begin{array}{l}\text { Fulfilment of responsibility for studies and research } \\
\text { integration. }\end{array}$ \\
\hline
\end{tabular}

Table 3. Implementation

At the stage of implementation, vice-rectors for research understand their responsibility through the quality, efficiency and transparency of performance, and deans of faculties respectively understand it as an institutional policy:

Implementation of the integration of studies and research quality. The responsibility is fulfilled through the quality of research and studies - "Orientation towards all levels of quality $<\ldots>$ studies of quality. Another aspect - research of quality. These main aspects are called the responsibility of university" [P5].

Implementation of efficient performance evaluation. The performance is carried out inconsistently, in the financial sense - "The mechanism of planning is not regulated in the way the accountability is. When [units] account for, we summarize the results for what they receive the funding." [P4].

Implementation of transparent university performance. The written document is identified with the transparent university performance - "Absolutely, everything is registered $<\ldots>$ When it is necessary to account for seven years, it is very useful. <...> that what our performance is, and it is transparent." [P4].

Fulfilment of institutional policy. The responsibility is moved to the state strategic level - "the higher education reform has turned to bring more disadvantages and now one of our main goals is to survive" [D1].

Fulfilment of institutional commitments. The responsibility is carried by institutional commitments - "each institution is responsible for that it would fulfil commitments timely and fairly" [D4]. 
Fulfilment of institutional responsibility. The responsibility is single-minded - "When there is an owner, the responsibility within [institution] may be $<\ldots>$ undefined. We are not owners. We must be responsible for our people and externally with all respect" [D8].

In line with the university strategic policy, deans of faculties implement other activities - they coordinate the creative activities, manage personnel, inform staff about current issues, involve them in decision making and provide certain self-determination for structural units. Deans of faculties fulfil these activities in both the study process and the research performance.

Vice-rectors for research maintain that they contribute to the satisfaction of societal need with their activities (as it is provided at the stage of planning), notwithstanding, deans of faculties relate the impact of their responsibility only to the integration of activities.

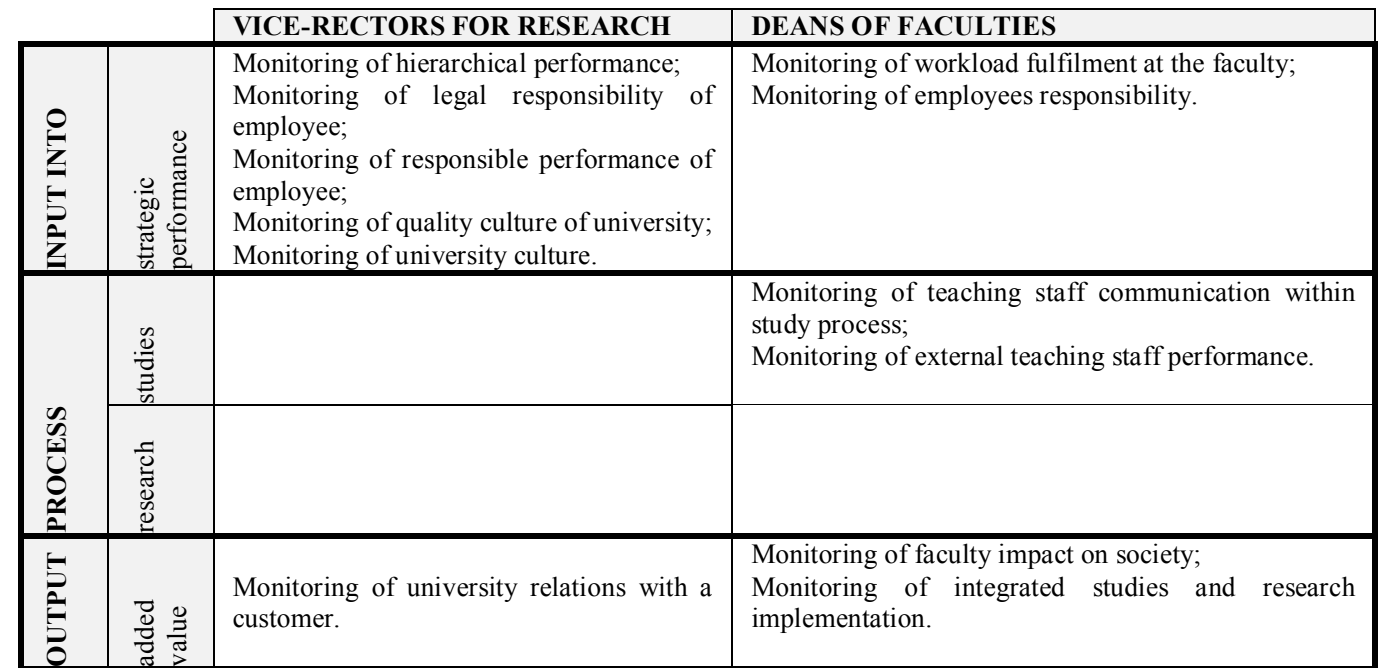

Table 4. Monitoring

Vice-rectors for research and deans of faculties engage staff at the stages of planning and implementation while, at the stage of monitoring, vice-rectors for research identify the hierarchy-based performance monitoring which is carried out through legal commitments and is related to the university culture. Vice-rectors for research share their responsibility with deans of faculties for the monitoring of staff responsibility. From the perspective of process, the responsibility of vice-rectors for research to monitor certain activities disappears. Deans of faculties feel more responsible for monitoring the study process, especially the activities of teaching staff.

The integration of activities and forethought of their impact is more typical of deans of faculties; meanwhile, vice-rectors for research orient their responsibility only towards the impact of performance:

Monitoring of university relations with a customer. The likely exchange relations demonstrate the benefit of institutional commitments - "a customer is close at hand and the same yesterday customer work now with us" [P6].

Monitoring of faculty impact on society. Alumni serve as the added value of faculty responsibility - "bachelor graduates are employed by speciality. <...> they do not emigrate!" [D8].

Monitoring of integrated studies and research implementation. The purpose of applied sciences is identified with an aspiration to improve the quality of studies - "[a researcher] makes some applied sciences for assurance of study quality" [D6]. The applied research performance of the researcher is put into practice during the study process through the methodological activities - "presentations $<_{\ldots}>$, various consultations $\langle\ldots>$ that is the way it is possible to take part in study process through methodological activities" [D6].

\begin{tabular}{|c|c|c|c|}
\hline & & VICE-RECTORS FOR RESEARCH & DEANS OF FACULTIES \\
\hline 实记 & 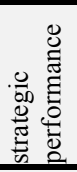 & $\begin{array}{l}\text { Evaluation of efficient performance; } \\
\text { Evaluation of fulfilment of departments commitments; } \\
\text { Annual accounting to university community. }\end{array}$ & $\begin{array}{l}\text { Evaluation of strategic development plan; } \\
\text { Evaluation of individual responsibility; } \\
\text { Evaluation of workload. }\end{array}$ \\
\hline \multirow{2}{*}{ 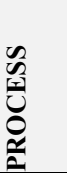 } & $\frac{\mathscr{n}}{\vec{E}}$ & & Evaluation of methodological activities. \\
\hline & $\underset{\mathscr{D}}{\mathbb{D}}$ & & \\
\hline
\end{tabular}




\begin{tabular}{|c|c|c|c|}
\hline & & VICE-RECTORS FOR RESEARCH & DEANS OF FACULTIES \\
\hline $\begin{array}{l}5 \\
5 \\
5 \\
0\end{array}$ & 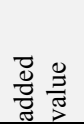 & $\begin{array}{l}\text { Evaluation of studies and research integration; } \\
\text { Accountability for society and government; } \\
\text { Annual accountability for society. }\end{array}$ & \\
\hline
\end{tabular}

\section{Table 5. Evaluation}

At the stage of evaluation, the responsibility of vice-rectors for research starts from the efficiency of performance which is based on the fulfilment of commitments by departments. Vice-rectors for research are engaged to present their evaluation to the university community and then later to society and government. Vicerectors for research do not indicate any activities from the perspective of process in studies and research, while deans of faculties identify only the evaluation of methodological activities:

Evaluation of methodological activities. The evaluation of results helps to fulfil the individual responsibility "[Methodological activities] are encouraged, evaluated, i.e. we wish that teaching staff continues working so, i.e. not being only engaged in the frontal work" [D6].

Unlike the process, vice-rectors for research understand the benefit of their responsibility to stakeholders while deans of faculties could not indicate what the evaluation of their responsibility brings:

Accountability for society and government. The accountability is externally implemented - "the accountability to the Ministry, society." [P4].

Annual accountability for society. The formal implementation of responsibility is made through the accountability within university - "We are accountable to society by introducing the annual reports. $<\ldots>$ [These reports] are published in newsletters, but the most important is that they all are available on the internet and are distributed (sent to the Ministry and then to the interested in). They are simply distributed. They are for internal use, but we share and send them to those who are interested in." [P4].

In general, both vice-rectors for research and deans of faculties pay less attention to the consistent operational life cycle in university internal management.

\section{Discussion}

Research findings show that universities highlight the organisational values of efficiency, creativity and transparency. The interrelation of these values with the university mission is fragmented. So far, studies and research, the inherent performance of any university, refer to university strategic policy. Their integration is weak at the planning stage; therefore, it is unclear how consistently these performances are fulfilled at other stages of management.

Results-based performance dominates; on-going process and evaluation of potential consequences are eliminated. Accordingly, the benefit of performance for stakeholders is poorly understood and managed.

Hierarchy-based performance evaluation is inadequate to organisational structure and subordination. Departments are directly accountable for their commitments not to the dean of faculty, but to the vice-rector for research.

The accountability to stakeholders is understood as the dissemination of reports, even for university community. In this case, a paradoxical situation arises - structural units provide the information for a report which is later introduced to themselves. The use of the same information is scarcely linked to how the university manages to achieve strategic goals. It indicates that university social responsibility from the ethical perspective is still undeveloped.

\section{REFERENCES}

[1] E. Gasca-Pliego, and J. C. Olvera-Garcia, Construir ciudadanía desde las universidades, responsabilidad social universitaria y desafíos ante el siglo XXI, Convergencia. Revista de Ciencias Sociales, 56, Mayo-Agosto 2011, 37-58.

[2] R. P. Hill, The Socially-Responsible University: Talking the Talk while Walking the Walk in the College of Business, Journal of Academic Ethics, 2(1), 2004, 89-100.

[3] G. Navarro Saldaňa, C. Pérez Villalobos, and M. G. González Navarro, Relación entre importancia atribuida a la RSC, jerarquía de valores y orientación social en directivos y académicos de una universidad chilena, LIBERABIT, 17(1), 2011, 85-92.

[4] C. Martínez, J. Rodriguez, G. Asprino, and B. Carvallo, Corresponsabilidad universitaria en la formación del capital social y responsabilidad social, available at: http://www.virtualeduca.info/ponencias2009/389/EDUCA\%202009.\%20ARG.doc (accessed 30 May 2013).

[5] I. Staškevičiūtè, and B. Neverauskas, The Intelligent University‘s Conceptual Model, Engineering Economics, 4(59), $2008,53-58$.

[6] K. Leja, A Socially Responsible University - an Attempt to Approach the System, Contemporary Management Quarterly, 2-3, 2010, 21-33.

[7] R. Gaete Quezada, La responsabilidad social universitaria como desafio para la gestión estratégica de la Educación Superior: el caso de España, Revista de Educación, 355, Mayo-agosto 2011, 109-133. 
[8] J. Kvedaravičius, and I. Dagyte, Mokslo sistemos pokyčių vadyba: ryškejjantys konceptualaus modelio kontūrai, Organizaciju vadyba: sisteminiai tyrimai, 38, 2006, 93-115.

[9] J. Kvedaravičius, and I. Dagytè, Akademinio jaunimo kūrybingumas: vadybos scenarijai. Kultūra ir aukštasis mokslas šiuolaikinèje visuomenèje, Viě̌asis administravimas, 4(16), 2007, 88-94.

[10] A. Marčinskas, V. Gudonienè, and G. Drukteinienė, Aukštojo mokslo instituciju ịvaizdis: šališki veiksniai, Informacijos mokslai, 40, 2007, 25-38

[11] A. B. Carroll, A Three-Dimensional Conceptual Model of Corporate Performance, Academy of Management Review, 4, 1979, 497505 .

[12] A. B. Carroll, The pyramid of corporate social responsibility, Business Horizons, 34(4), 1991, 39-48.

[13] A. B. Carroll, Corporate Social Responsibility. Evolution of Definitional Construct, Business and Society, 38(3), 1999, $268-295$.

[14] J. Ruževičius, J. Studijų kokybès vadybos sistemų tyrimas, Ekonomika, 80, 2007, 51-69.

[15] C. Soares, Corporate Versus Individual Moral Responsibility, Journal of Business Ethics, 46(2), 2003, 143-150.

[16] F. Vallaeys, C. de la Cruz,and P. Sasia, Responsabilidad Social Universitaria. Manual primeros pasos (Mexico D. F.: McGraw Hill, 2009).

[17] B. Conraths, and H. Smidt, The Funding of University-Based Research and Innovation in Europe: An Exploratory Study (Brussels: EUA Publications, 2005).

[18] J. Wieland, Values Management System ZfW: a new standard for values driven management, in J. Wieland (Ed.), Standards audits for ethics management systems: the European perspective (Berlin/ Heidelberg/ New York: Springer, 2003), 3-23.

[19] N. Vasiljevienè, Vertybinių švietimo sistemos pokyčių problemos naujuose aukštojo mokslo kontekstuose, Societal Innovations for Global Growth, 1(1), 2012, 1070-1083.

[20] R. M. Rosenzweig, Universities Change, Core Values Should Not, Issues in Science \& Technology, 16(2), Winter 1999/2000, 5964.

[21] S. Boaventura de Sousa, The university in the twenty-first century. Toward a democratic and emancipatory university reform, in M. W. Apple et al. (Eds.), The Routledge International Handbook of the Sociology of Education (London and New York: Routledge, 2010), 274-282.

[22] D. Bridges, Research for Sale: moral market or moral maze?, British Educational Research Journal, 24(5), $1998,598-606$. 